\title{
Sexual dimorphism in the assessment of mineral apposition rate during osteoporosis
}

\author{
Dimorfismo sexual na avaliação da taxa de aposição mineral durante a osteoporose \\ Dimorfismo sexual en la evaluación de la tasa de aposición mineral durante la osteoporosis
}

Received: 01/20/2021 | Reviewed: 01/26/2021 | Accept: 01/27/2021 | Published: 02/03/2021

\author{
Juliana Zorzi Coléte \\ ORCID: https://orcid.org/0000-0001-9957-2073 \\ Universidade Estadual Paulista "Júlio de Mesquita Filho", Brazil \\ E-mail: odontozorzi@gmail.com \\ Pedro Henrique Silva Gomes Ferreira \\ ORCID: https://orcid.org/0000-0002-8936-3662 \\ Universidade Estadual Paulista "Júlio de Mesquita Filho", Brazil \\ E-mail: pedroferreirabmf@gmail.com \\ Paula Buzo Frigério \\ ORCID: https://orcid.org/0000-0002-5012-5093 \\ Universidade Estadual Paulista "Júlio de Mesquita Filho", Brazil \\ E-mail: paula.frigerio@outlook.com \\ Igor de Oliveira Puttini \\ ORCID: https://orcid.org/0000-0001-5707-0614 \\ Universidade Estadual Paulista "Júlio de Mesquita Filho", Brazil \\ E-mail: igorputtini@gmail.com \\ Gustavo Momesso \\ ORCID: https://orcid.org/0000-0003-4529-683X \\ Universidade Estadual Paulista "Júlio de Mesquita Filho", Brazil \\ E-mail: gustavomomesso@gmail.com \\ Fábio Roberto de Souza Batista \\ ORCID: https://orcid.org/0000-0002-5105-7686 \\ Universidade Estadual Paulista "Júlio de Mesquita Filho", Brazil \\ E-mail: fabiorsbatista@gmail.com \\ Roberta Okamoto \\ ORCID: https://orcid.org/0000-0002-6773-6966 \\ Universidade Estadual Paulista "Júlio de Mesquita Filho", Brazil \\ E-mail: roberta.okamoto@unesp.br
}

\begin{abstract}
The objective of this study was to evaluate the daily maxillary and tibial bone mineral apposition rate of ovariectomized rats and orchiectomized rats through confocal laser microscopy. Twenty-four animals were divided into 4 groups (SHAMF, OVX, SHAMM and ORQ). Six rats were distributed to the SHAMF group (submitted to fictitious surgery); six rats to the OVX group (submitted to bilateral ovariectomy); six rats to the SHAMM group (submitted to fictitious surgery) and six rats to the ORQ group (submitted to bilateral orchiectomy). On the 60th day after the surgical procedures the animals received $20 \mathrm{mg} / \mathrm{kg}$ of calcein and after 24 days $20 \mathrm{mg} / \mathrm{kg}$ of alizarin red was administered. The euthanasia was performed 18 days after the last fluorochrome administration. The histological slides obtained were submitted to confocal microscopy analysis and then dynamic histomorphometry was performed to obtain the daily mineral apposition rate (MAR). In the tibias, the values of MAR were higher for the SHAMF group $(\mathrm{P}<0.05)$ (mean: 37.1 $\mu \mathrm{m}^{2} /$ day) compared to the ORQ group (mean: $\left.7.16 \mu \mathrm{m}^{2}\right)$. In the jaws, the values were higher for the SHAMF group $(\mathrm{P}<0.05)$ (mean: $5.175 \mu \mathrm{m}^{2} /$ day) compared to the SHAMM group (mean: $1.84 \mu \mathrm{m}^{2}$ ), OVX (mean: $3.027 \mu \mathrm{m}^{2}$ ) and ORQ group (mean: $1.56 \mu \mathrm{m}^{2}$ ). It can be concluded that the female gender, regarding the characteristics of the maxillary and tibial bones, presented a daily mineral bone apposition rate higher than the male gender, mainly in the maxillary bone, presenting a statistically significant difference between all groups studied.
\end{abstract}

Keywords: Osteoporosis; Sex characteristics; Microscopy.

\section{Resumo}

O objetivo desse estudo foi avaliar a taxa de aposição mineral óssea diária maxilar e tibial de ratas ovariectomizadas e ratos orquiectomizados através da microscopia confocal a laser. Vinte e quatro animais foram divididos em 4 grupos (SHAMF, OVX, SHAMM e ORQ). Sendo distribuídos 6 ratas para o grupo SHAMF (submetidas à cirurgia fictícia); 6 ratas para o grupo OVX (submetidas à ovariectomia bilateral); 6 ratos para o grupo SHAMM (submetidos à cirurgia fictícia) e 6 ratos para o grupo ORQ (submetidos à orquiectomia bilateral). No $60^{\circ}$ dia após os procedimentos cirúrgicos, os animais receberam $20 \mathrm{mg} / \mathrm{kg}$ de calceína e após 24 dias, foi administrado $20 \mathrm{mg} / \mathrm{kg}$ de vermelho de alizarina. A eutanásia foi realizada após 18 dias da administração do último fluorocromo. As lâminas histológicas 
obtidas foram submetidas à análise de microscopia confocal e posteriormente realizado a histomorfometria dinâmica para obtenção da taxa de aposição mineral diária (MAR). Nas tíbias, os valores de MAR foram maiores para o grupo SHAMF $(\mathrm{P}<0,05)$ (media: 37,1 $\mathrm{m}^{2} /$ dia) em comparação ao grupo ORQ (media: 7,16 $\mu \mathrm{m}^{2}$ ). Nas maxilas, os valores foram maiores para o grupo SHAMF $(\mathrm{P}<0,05)$ (media: $5,175 \mu \mathrm{m}^{2} /$ dia) em comparação aos grupos SHAMM (media: 1,84 $\mu \mathrm{m}^{2}$ ), OVX (media: 3,027 $\mu^{2}$ ) e ORQ (media: 1,56 $\mu \mathrm{m}^{2}$ ). Conclui-se que o gênero feminino, com relação as características do osso maxilar e tibial, apresentou uma taxa de aposição óssea mineral diária superior ao gênero masculino, principalmente no osso maxilar, apresentando diferença estatisticamente significante entre todos os grupos estudados.

Palavras-chave: Osteoporose; Caracteres sexuais; Microscopia.

\section{Resumen}

El objetivo de este estudio fue evaluar la tasa de aposición mineral ósea maxilar y tibial diaria de ratas ovariectomizadas y ratones orquiectomizados usando microscopía láser confocal. Veinticuatro animales fueron divididos en 4 grupos (SHAMF, OVX, SHAMM y ORQ). Se distribuyeron seis ratas al grupo SHAMF (cirugía ficticia); seis ratas al grupo OVX (sometido a una ovariectomía bilateral); seis ratones al grupo SHAMM (cirugía ficticia) y seis ratones al grupo ORQ (sometido a una orquiectomía bilateral). Al $60^{\circ}$ día después de los procedimientos quirúrgicos, los animales recibieron $20 \mathrm{mg} / \mathrm{kg}$ de calceína y al cabo de 24 días, se administraron 20 $\mathrm{mg} / \mathrm{kg}$ alizarina. La eutanasia se realizó 18 días después de la última administración de flúor. Los portaobjetos histológicos obtenidos se sometieron a análisis de microscopía confocal y posteriormente se realizó una histomorfometría dinámica para obtener la tasa de aposición mineral diaria (MAR). En la tibia, los valores de MAR fueron más altos para el grupo SHAMF $(\mathrm{P}<0,05)$ (media: $37,1 \mu \mathrm{m}^{2} /$ día) en comparación con ORQ $\left(\mathrm{media} \mathrm{7,16} \mu \mathrm{m}^{2}\right)$. En las mandíbulas, los valores fueron más altos para el grupo SHAMF $(\mathrm{P}<0,05)$ (media: $\left.5,175 \mu \mathrm{m}^{2} / \mathrm{dí}^{2}\right)$ en comparación con el grupo SHAMM (media: $1,84 \mu \mathrm{m}^{2}$ ), OVX (media: 3,027 $\mu \mathrm{m}^{2}$ ) y el grupo ORQ (media: $1,56 \mu \mathrm{m}^{2}$ ). Se puede concluir que el género femenino, en lo que respecta a las características de los huesos maxilar y tibial, mostró una tasa de aposición mineral ósea diaria superior a la del género masculino, especialmente en el hueso maxilar, mostrando una diferencia estadísticamente entre todos los grupos estudiados.

Palabras clave: Osteoporosis; Caracteres sexuales; Microscopia.

\section{Introduction}

Osteoporosis is a multifactorial systemic disease characterized by reduction of bone mass and modification of the microarchitecture of bone tissue, occurring in both sexes (Stevenson et al., 2005; Akbaba et al., 2013). The main cause of osteoporosis in women is increased bone resorption (Ramalho-Ferreira et al., 2015). However, in males, it is caused by reduced bone formation (Farahmand et al., 2016). A lower bone density manifests itself when the resorption excels the neoformation, compromising the bone/implant interface (Drage et al., 2007), characterizing the osteoporosis condition, observed mainly in women in the post menopause phase (Drake \& Khosla, 2012). However, it is also reported in men, with higher incidence from the sixth decade of life (Drake \& Khosla, 2012; Giusti \& Bianchi, 2014).

In women, one of the main characteristics of osteoporosis is the drop in estrogen production, which leads to an increase in cytokine release that induces osteoclastogenesis, thus increasing the rate of bone remodeling, characterized by an exacerbated bone resorption overlapping bone formation, which results in a total imbalance of bone microarchitecture, where bone is highly porous and fragile (Aubin \& Bonnelye, 2000; NIH, 2001). Bone turnover is accelerated during osteoporosis, resulting in bone resorption without compensation for new bone tissue formation, which would be a contraindication for large bone reconstructions or dental implants, since a quality bone tissue is essential for oral rehabilitation with favorable prognosis (Stevenson et al., 2005; Manolagas \& Jilka, 1995; Luvizuto et al., 2010).

Among the causes of osteopenia in males, besides advanced age, hypogonadism can also be directly related, resulting in a high rate of remodeling and acceleration in bone loss (Mittan et al., 2002; Kaufman et al., 2014). Testosterone aromatization in oestradiol plays an important role in the regulation of bone homeostasis in men, limiting age-related bone loss (Riggs et al., 2002; Van Pottelbergh et al., 2003; Gennari et al., 2004; Vanderschueren et al., 2004). Other factors described in the literature are: vitamin D deficiency, decrease in calcium absorption, poor diet or even senility (Kaufman \& Goemaere, 2008; Kaufman et al., 2014). 
In consequence, several drugs have been developed and have been studied for osteoporosis treatment (Seeman, 2003; Häuselmann, H. J., \& Rizzoli, 2003). Most of the anti-osteoporotic therapies involve anti resorption drugs, such as estrogen substitution, selective modulator of estrogen receptors (SERMS) and biphosphonates. The action of these drugs produces a reduction in bone turnover and consequent inhibition of bone resorption (Marie et al., 1993; Marie, 2006). These effects are beneficial for bone tissue, however the long-term use of bisphosphonates has been related to the development of osteonecrosis related to the mandible (Ruggiero et al., 2014; Marx et al., 2007).

Therefore, the proposal of this study was to evaluate the daily maxillary and tibial bone mineral apposition rate of ovariectomized rats and orchiectomized rats by fluorochromes analysis through epifluorescence histometry.

\section{Methodology}

\subsection{Experimental groups}

This study was approved by the Ethics Committee for the Use of Animals (00706-2015) and (00685-2015) of the School of Dentistry of Araçatuba, Universidade Estadual Paulista (UNESP) following the recommendations of Arrive Guidelines (Kilkenny et al., 2012). A total of 24 rats were used, being 12 adult females and 12 adult males (Rattus Norvegicus Albinus, Wistar), three months old, weighing approximately $250 \mathrm{~g}$. The animals were kept in cages, air-conditioned environment, fed with balanced dry feed (NUVILAB, Curitiba PR, Brazil) and water ad libitum until euthanasia.

The animals were divided into four groups $(n=6)$ according to gender, SHAMF, OVX, SHAMM and ORQ. In the SHAMF GROUP six rats were submitted to a fictitious surgery, which is a surgical procedure with the purpose of exposing the ovaries, so that the rats were exposed to the same surgical stress of the ovariectomized group. In the OVX GROUP six rats were submitted to bilateral ovariectomy. Before ovariectomy the rats were submitted to estrous cycle analysis for more than three regular cycles. At SHAMM GROUP six rats were submitted to fictitious surgery, only with exposure of the testicles without removal of them, to share the same surgical stress of the orchiectomized group. At ORQ GROUP six rats were submitted to bilateral orchiectomy. In the chronological sequence, day 0 refers to the day of ovariectomy in females, orchiectomy in males and fictitious surgeries. On the 60th day after the surgeries, $20 \mathrm{mg} / \mathrm{kg}$ (Ramalho-Ferreira et al., 2017) of calcein (Sigma Chemical Company, St. Louis, Missouri) was administered intramuscularly and after 24 days $20 \mathrm{mg} / \mathrm{kg}$ (Pedrosa et al., 2009) of alizarin red (Sigma Chemical Company) was administered. The fluorochromes were diluted to $1.5 \mathrm{~mL}$ in deionized water with a magnetic stirrer (Max Labor, Presidente Prudente, SP). The animals were euthanized through a lethal dose of anesthetic (150 mg/kg; Tiopental Cristália Ltda.; Itapira, SP, Brazil) 18 days after the application of the alizarin red. The chronological sequence of the events is illustrated in Figure 1.

Figure 1 - Experimental study design.

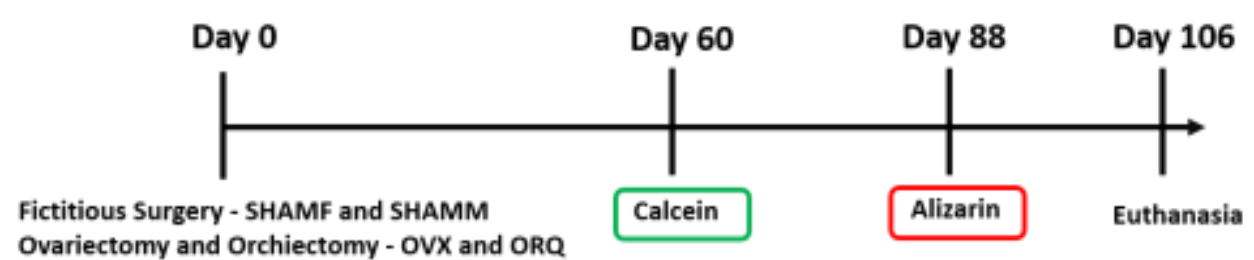

Source: Authors.

\subsection{Estrous cycle}

To ensure that the rats used in the experiments are in the normal estrous cycle, they were placed in individual cages and daily 1-2 drops of saline solution were introduced into the interior of the vagina, which were then aspirated and placed on a 
histological slide for immediate microscopic reading of the technique (Long \& Evans, 1922) for recognition of the phases of the estrous cycle (Annibali et al., 2012; Alghamdi et al., 2014). The rats were used after obtaining 2 to 3 regular estrous cycles.

\subsection{Bilateral ovariectomy}

The rats were anesthetized with Xylazine Hydrochloride (Xylazine - Coopers, Brazil, Ltda.) and Ketamine Hydrochloride (Injectable Ketamine Hydrochloride, Fort Dodge, Saúde Animal Ltda. ) and then were immobilized on a surgical board in lateral decubitus position, an incision of $1 \mathrm{~cm}$ was made in the flanks, divulsion by planes of subcutaneous tissue and then the peritoneum in order to have access to the abdominal cavity. Next, the ovaries and uterine horns were located which were lacquered with Polyglactin 910 4-0 thread (Vicryl ${ }^{\text {tm }}$ - Jhonson \& Jhonson, New Brunswick, NJ, USA). After this, the ovaries were removed. Finished, the suturing was done by planes with Polyglactin 910 4-0 thread (Vicryl ${ }^{\mathrm{tm}}-$ Jhonson \& Johnson, New Brunswick, NJ, USA). The surgical steps of ovariectomy were according to the technique described by Sayed et al., 2013. The SHAMF group rats underwent the same procedure, but only surgical exposure of the uterine horns and ovaries without their respective lacquering and removal was performed.

\subsection{Bilateral orchiectomy}

All rats were initially anesthetized with Coopazine (Xilazine-Coopers, Brazil, Ltda) and Vetaset (ketamine hydrochloride, injectable, Fort Dodge, Saúde Animal, Ltda) with the dosages recommended by the manufacturer. After the anesthesia was performed the antisepsis with Polyvinyl Pyrrolidone iodide (Chemical and Pharmaceutical Industry Rioquímica Ltda, Brazil).

In the ORQ group the incisions were made in both scrotal sacs, with the testicles being exposed. With the hemostatic forceps the spermatic funicle was presented, with simultaneous individualization, lacquering and sectioning of the ductus deferens and vascular pedicle. The testicles were removed, and surgical wounds were sutured with 910 4-0 polyglactin thread (Ethicon, Johnson \& Johnson, São José dos Campos, SP, Brazil). This procedure was validated by Seifi et al., 2015 after confirmation of endogenous testosterone decrease by the Elisa test. The rats of the SHAMM group underwent the same procedure, but it was only performed to the surgical exposure of the testicles without their removal, in order to submit the animals of this group to the same surgical stress of the ORQ group (Al-Shahat et al., 2011). As postoperative, penicillin benzathine $\mathrm{G}$ for veterinary use was administered in a single intramuscular dose $(0.2 \mathrm{ml} / \mathrm{kg}$, Fort Dodge Animal Health Ltd., Campinas, São Paulo, Brazil).

\subsection{Collection of materials}

After 18 days of applying the alizarin red, the rats were euthanasiated. After euthanasia, the tibias and hemimaxillas on the right side were removed and prepared for laser confocal microscopy analysis.

\subsection{Laboratory processing of confocal laser microscopy}

The pieces obtained were fixed in $10 \%$ paraformaldehyde solution. After 48 hours, the specimens were washed in running water for 24 hours; dehydrated in increasing concentrations of alcohols; soaked and infiltrated in a solution of acetone and slow methyl methacrylate (PMMAL) (Clássico, Artigos Odontológicos Clássico, São Paulo, SP, Brazil) in a proportion of 1:1. In the sequence, they received 3 baths of PMMAL, being that in the last bath it was added the $1 \%$ benzoyl peroxide catalyst (Riedel - De Haën AG, Seelze - Hannover, Germany). The last bath (PMMAL and catalyst) was performed with the parts placed in glass flasks with caps which were kept at a temperature of $37^{\circ} \mathrm{C}$, for 5 days until the resin is polymerized. After polymerization the blocks containing the specimens were initially reduced with a "Maxcut" drill mounted on a Kota 
bench motor (Strong 210, São Paulo, SP, Brazil), parallel to the long axis of the hemimaxyl and tibia (sagittal plane). Progressive manual wear in automatic polishing (ECOMET 250PRO/AUTOMET 250, Buehler, Lake Bluff, IL, USA) with 120, 300, 400, 600, 800 and 1200 grain sandpapers (Carbimet 2, Buehler, Lake Bluff, IL, USA), under fluorescent light, up to $150 \mu \mathrm{m}$ thickness measured by digital pachymeter (Mitutoyo, Pompeia, SP, Brazil), continued. The cuts obtained were mounted on histological blades with mineral oil (Petrolato líquido, Mantecor, Taquara, RJ, Brazil) and fixed with laminules and enamel to prevent the oil from spoiling, preventing the cut from drying out.

\subsection{Scanning by confocal laser microscopy}

The methodology used for the confocal analysis followed the parameters described by (de Oliveira Puttini et al., 2019 and Ramalho-Ferrreira et al., 2015). The longitudinal sections of the tibia and maxillary bone adjacent to the apical third of the upper central incisor were obtained using the Leica CTR 4000 CS SPE microscope (Leica Microsystems, Heidelberg, Germany), using a $10 \mathrm{X}$ objective (original magnification 100). The hemimaxillary area was chosen considering the bone tissue adjacent to the right upper incisor as reference. Therefore, the tooth was taken as a reference, and then the area of bone tissue around this tooth was evaluated in each sample. In the tibia, the area was chosen taking as reference the tibial metaphysis. Images of $1 \mathrm{~mm}$ in height and width were obtained corresponding to the dimensions in $512 \times 512$ pixels of optical sections. The images were scanned with $2 \mu \mathrm{m}$ slices per slice for 2.5 minutes. Thus, for the total scanning of each slide at 56 $\mu \mathrm{m}, 28$ cuts were obtained. The barrier filters used were BP 530/30 nm and LP $590 \mathrm{~nm}$ combined with the activation of DD 488/568 and for each of the fluorochromes the photomultiplier was 534 for calcein and 357 for alizarin. The images started from the beginning of fluorescence, thus representing, in our methodological approach, the beginning of calcification or bone formation (calcium precipitation in the organic matrix of collagen). The images obtained by the confocal microscope were reconstructed and thus the tibial and maxillary bone presented the overlapping of the two fluorochromes (calcein and alizarin). These images were saved in TIFF format and transported to ImageJ software (Image Processing and Analysis Software, Ontario, ON, Canada). This program uses a quantitative method (Pereira et al., 2018), to determine the amount of new and old bone that has been formed, so through the "color threshold" tool, each image corresponding to the experimental groups (SHAMF, OVX, SHAMM and ORQ) was standardized according to the hue, saturation and brightness, for evidence of the analyzed fluorochromes. First, the green color was evidenced (calcein, old bone) and by the tool "measure" the program provided the corresponding area in $\mu \mathrm{m} 2$. The same procedure was performed for the red color (alizarin, new bone), obtaining the data regarding the dynamics of the alveolar bone tissue.

The bone turnover, in this methodological approach, is represented by the difference between old bone (green) and new bone (red) that receives the denomination of active mineralization surface. Fluorochromes are chemical compounds that have the property of binding to calcium at the time of precipitation in the bone matrix. Therefore, the extent of fluorochrome marking represents the amount of calcium precipitation, thus allowing the measurement of the bone formation event. Another aspect to be considered is the period in which the fluorochromes were injected; as the first was calcein (green), the bone marked (calcium precipitation) with the green fluorochrome represents the old bone. The last fluorochrome injected was alizarin; therefore, the marked bone (calcium precipitation) with the red fluorochrome represents the new bone, that is, the active surface of mineralization (Dempster et al., 2013). Considering these points, it can be said that the different colors represent the different periods of bone formation (Ramalho-Ferreira et al., 2015; Wang et al., 2014; Hassler et al., 2014). The dynamics of bone tissue is represented by bone remodeling, observed through calcium precipitation that occurs in bone formation represented by red fluorochrome. The higher the prevalence of red fluorescence, the greater the active surface of mineralization, while green fluorescence represents the previous (old) bone (Figure 2). 
Figure 2 - Photomicrographs obtained using confocal microscopy. (a) Bone area marked with calcein (green); (b) bone area marked with alizarin (red); and (c) overlapping images of both fluorochromes.
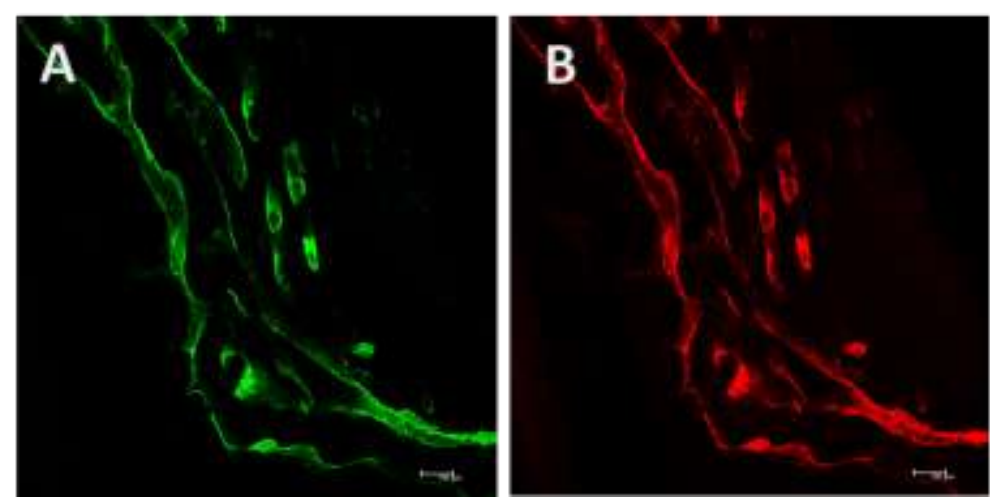

Source: Authors.

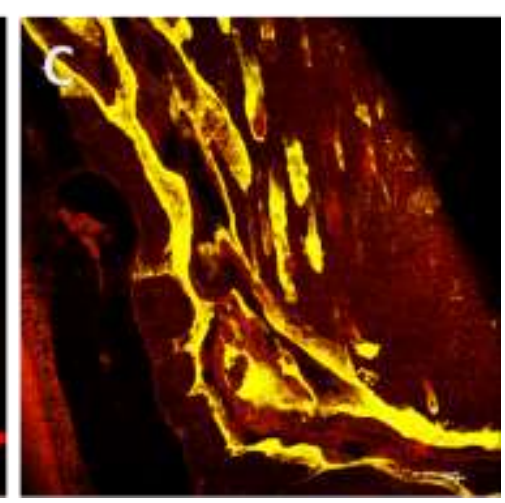

\subsection{Histometric analysis}

To obtain the mineral apposition rate (MAR) of the fluorochrome area, the images were transported to the ImageJ software (Software Processing and Image Analysis, Ontario, Canada) for the standardization of each image. Then, the "direct" tool was selected and a line was made between the precipitation from the beginning of alizarin (red marking) to the end of the precipitation of calcein (green marking). The values were divided by 28 , which refers to the period of days between the calcein and alizarin injections. These results represent the daily precipitation of calcium, an important parameter that characterizes bone dynamics (Dempster et al., 2013).

\subsection{Statistical analysis}

For the statistical analysis, the data obtained were submitted to a normality and homoscedasticity test (Shapiro-Wilk test, $\mathrm{P}<0.05)$ which was used to evaluate the distribution of the samples, which were parametric. After confirmation of their normal distribution, the Anova One Way test was followed by Tukey's test for multiple comparisons when necessary. The tests were performed using GraphPad Prism version 7.01. For all data, the level of significance was 5\% (P <0.05).

\section{Results}

\subsection{Fluorochromic precipitation}

The administration of fluorochromes established the formation of fluorescent areas by the precipitation of calcium in the bone matrix, referring to the calcein injected 60 days after ovariectomy/orchiectomy surgeries and the alizarin injected 88 days after ovariectomy/orchiectomy surgeries.

Regarding the experimental design used in this study, the green coloration (calcein) refers to the old bone (fluorochrome injected at 60 days) and the red coloration (alizarin) refers to the new bone (fluorochrome injected at 88 days). Figures 3 and 4 represent photomicrographs of the fluorochrome areas of the tibia and jaw, they show the precipitation of old bone (calcein) and new bone (alizarin). 
Figure 3 - Photomicrographs of the fluorochrome areas of the tibiae.

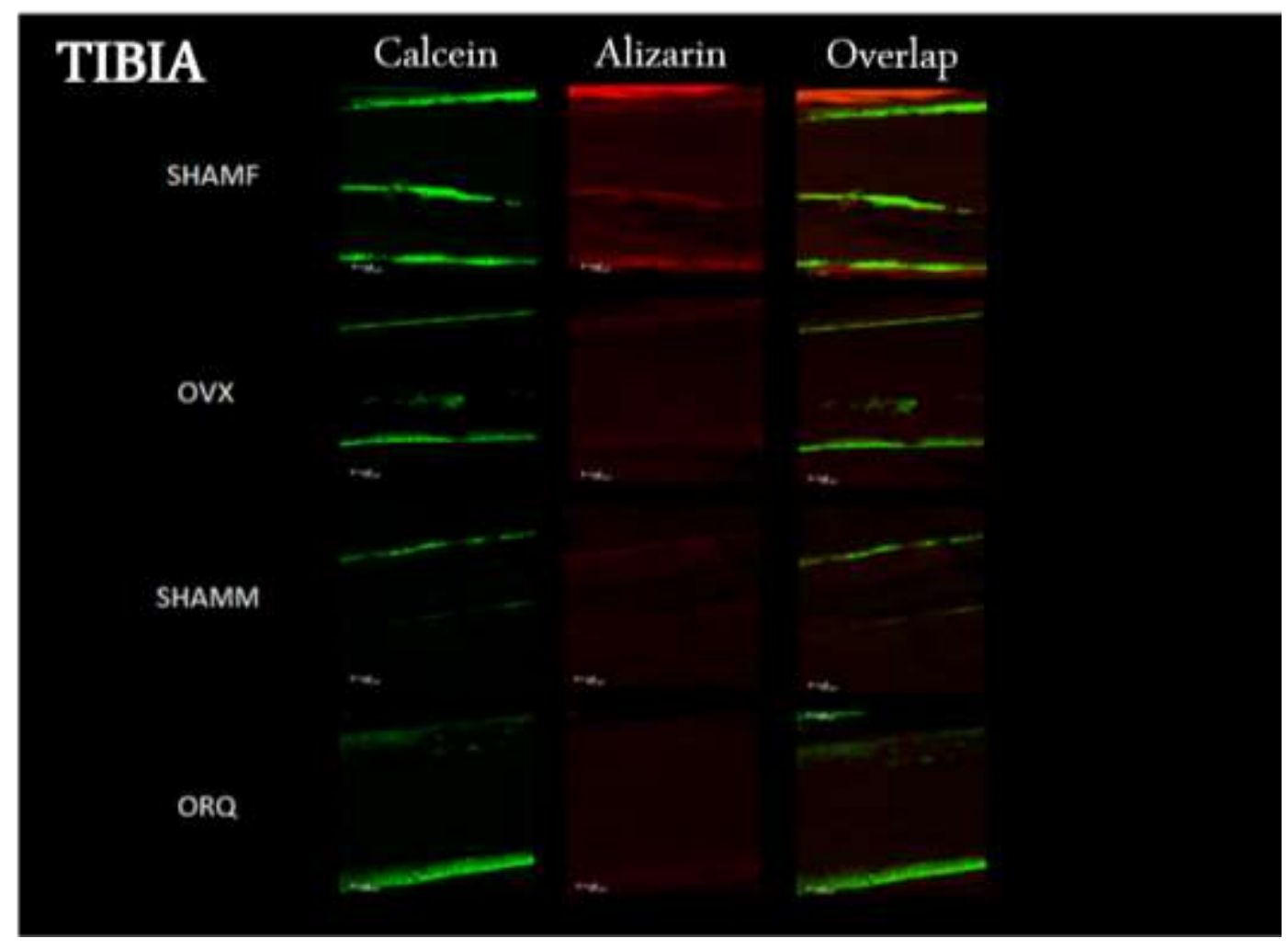

Source: Authors.

Figure 4 - Photomicrographs of the fluorochrome areas of the jaws.

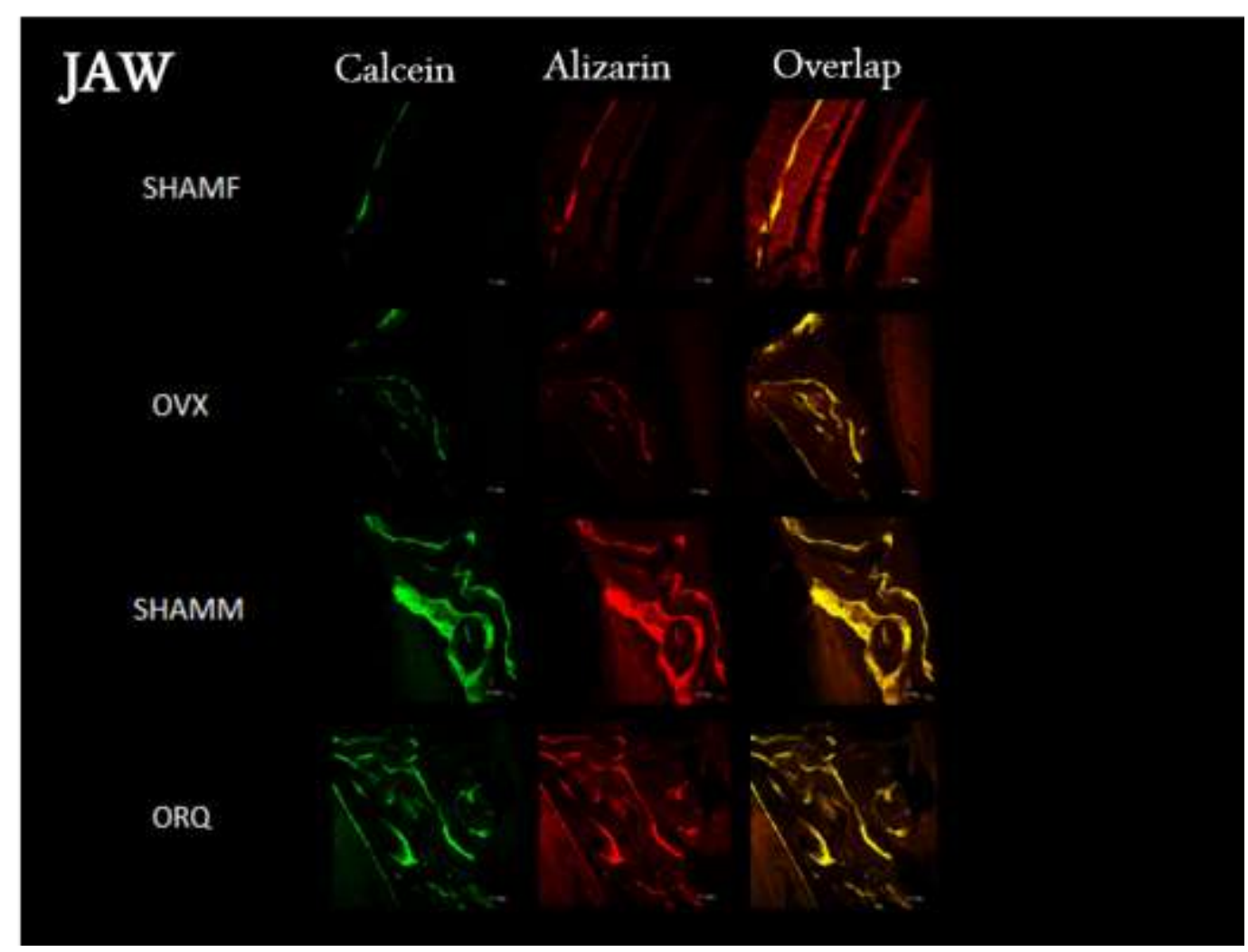

Source: Authors. 


\subsection{Daily mineral apposition rate (MAR) in the tibiae}

In the tibias, the values on the daily mineral apposition rate (MAR) were higher for the SHAMF group $(\mathrm{P}<0.05)$ (average: $37.1 \mu \mathrm{m}^{2} /$ day) compared to the ORQ group (average: $7.16 \mu \mathrm{m}^{2}$ ). Likewise, the values on the daily mineral apposition rate (MAR) were higher for the SHAMM group ( $\mathrm{P}<0.05)$ (mean: $29.38 \mu \mathrm{m}^{2} /$ day) compared to the ORQ group (mean: $7.16 \mu \mathrm{m}^{2}$ ). There was no significant difference between the SHAMF (median: $37.1 \mu \mathrm{m}^{2} /$ day) and OVX (median: $21.28 \mu \mathrm{m}^{2}$ ) groups, and between the SHAMM and OVX groups) (Grapich 1).

Graphic 1 - Values on the rate of daily mineral apposition in the tibiae between the experimental groups (SHAMF, SHAMM, OVX and ORQ).

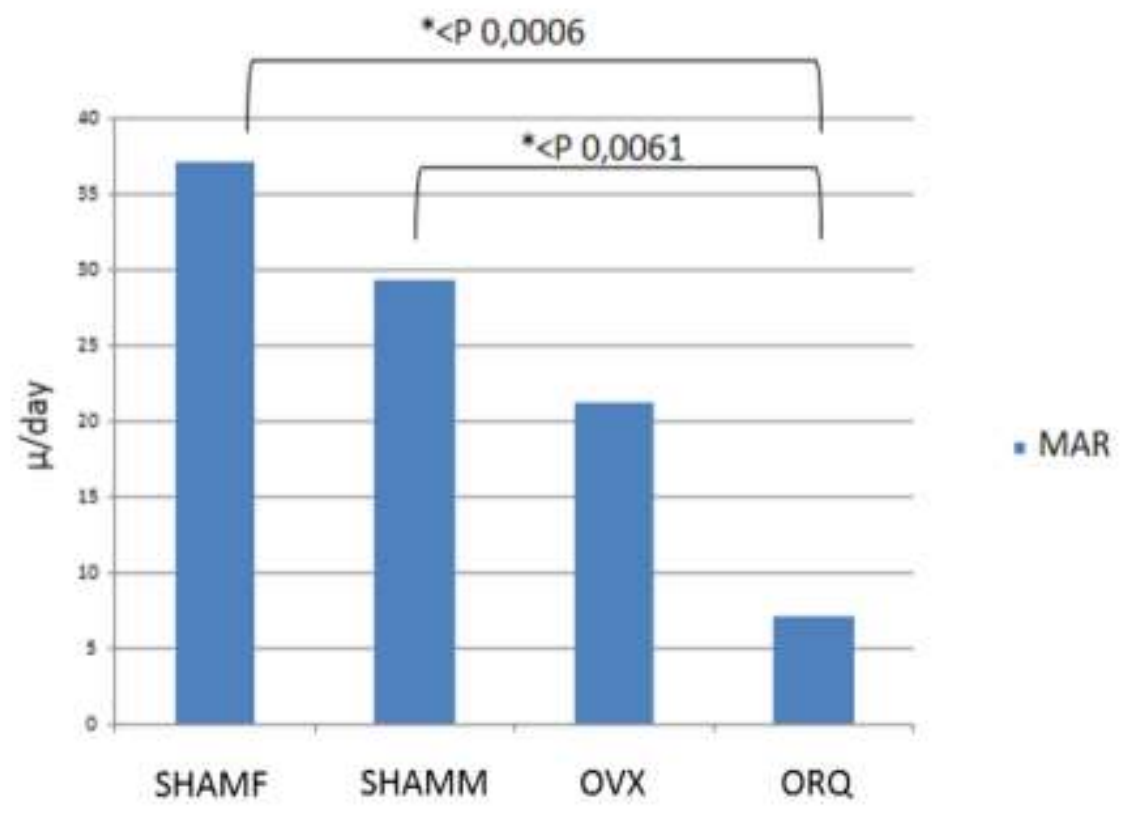

Source: Authors.

\subsection{Mineral apposition rate (MAR) in the jaws}

In the jaws, the values on the daily mineral apposition rate (MAR) were higher for the SHAMF group $(\mathrm{P}<0.05)$ (average: $5.175 \mu \mathrm{m}^{2} /$ day) compared to the SHAMM groups (average: $1.84 \mu \mathrm{m}^{2}$ ), OVX (average: $3.027 \mu \mathrm{m}^{2}$ ) and ORQ (average: $1.56 \mu \mathrm{m}^{2}$ ). Thus, there was a significant difference in the daily mineral apposition rate between all groups (Grapich 2). 
Graphic 2 - Values on the daily mineral apposition rate in the jaws between the experimental groups (SHAMF, SHAMM, OVX and ORQ).

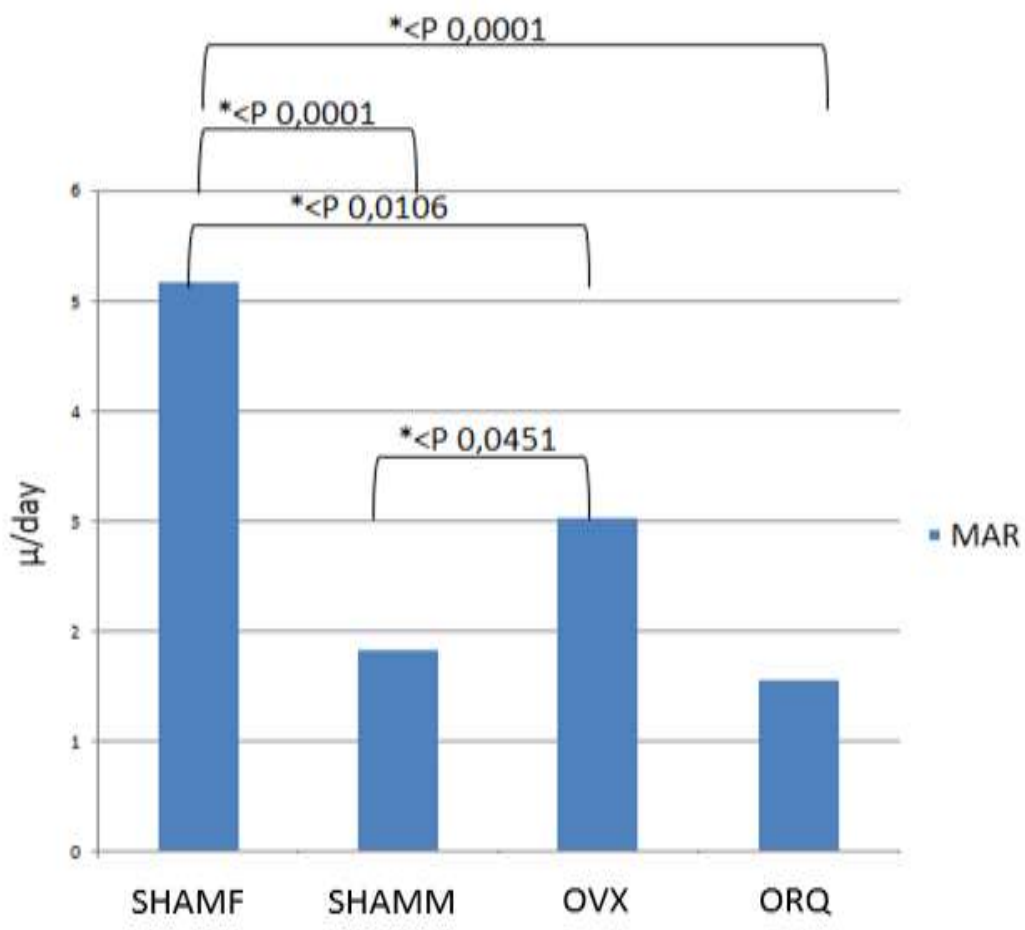

Source: Authors.

This work made the comparison between healthy and castrated male and female rats. And it was possible to notice through the analyses presented that the male castrated rats showed a greater sensitivity to male hormone loss, thus, they had a lower calcium precipitation rate than female rats, both for the SHAMF tibial bone $\left(37.1 \mu \mathrm{m}^{2} /\right.$ day $)$ in relation to the SHAMM group $\left(29.38 \mu \mathrm{m}^{2} /\right.$ day) and OVX $\left(21.28 \mu \mathrm{m}^{2}\right)$ vs. ORQ $\left(7,16 \mu \mathrm{m}^{2}\right)($ Grapich 1$)$, and for SHAMF maxillary bone $\left(5,175 \mu \mathrm{m}^{2} /\right.$ day) compared to SHAMM $\left(1,84 \mu \mathrm{m}^{2}\right)$ and OVX $\left(3,027 \mu \mathrm{m}^{2}\right)$ vs. ORQ $\left(1,56 \mu \mathrm{m}^{2}\right)$ groups (Grapich 2).

\section{Discussion}

In women, during menopause, estrogen deficiency occurs, leading to the development of postmenopausal osteoporosis (Oliveira \& Guimarães, 2015). This occurs due to the fact that, in low concentrations, estrogen negatively modulates bone remodeling, causing an increase in osteoclastic bone resorption. This process is due to the increase in plasma concentration of interleukin 1 (IL-1) and tumor necrosis factor (TNF- $\alpha$ ) that stimulate the production of interleukin 6 (IL-6) and macrophage colony stimulating factor (M-CSF) (McClung et al., 2006; Pacifici et al., 1989). This cascade favors the connection between RANKL and RANK, activating osteoclastogenesis and bone resorption (Oliveira \& Guimarães, 2015).

Thus, the experimental animal model OVX (rat submitted to ovariectomy) is already consolidated in the literature as an osteopenic inductor by means of estrogen deficiency that is established after ovarian removal (Ramalho-Ferreira et al., 2015; Giusti \& Bianchi, 2014; NIH, 2001; Stevenson et al., 2005; Luvizuto et al., 2010). Therefore, ovariectomy causes an estrogen deficiency in rats leading to increased rates of bone resorption and bone formation, with resorption exceeding formation. As a result, bone remodeling increases in ovariectomized rats. The loss of bone mass is accompanied by a significant increase in bone remodeling, as indicated by improved levels of bone remodeling markers, S-ALP and S-OC (Farahmand et al., 2016). 
In the past, it was thought that male osteoporosis did not exist due to testosterone persisting at functional levels until the age of 70. For a long time, osteoporosis was considered a woman's disease, but today it is also being recognized as a concern and a public health issue for men (Kaufman et al., 2014). Unlike what happens with postmenopausal women, the reduction of bone neoformation is age related in men, combined with poor diet and hormonal levels making anabolic agents a logical treatment option for men with osteoporosis (Gennari et al., 2004). A high serum parathyroid hormone (PTH) level and bone loss occurs in elderly men due to a drop in calcium absorption in the intestine and high prevalence of vitamin deficiency (Mittan et al., 2002; Kaufman et al., 2014). In men, testosterone and estrogen are important for the gain and maintenance of bone mass (Kaufman et al., 2014), but the free or bioavailable levels of testosterone and estradiol decrease with age, due to the increase in the serum level of sex hormone binding globulin (SHBG) and failure to compensate the hypothalamus/hipophysis/testrium axis (Kaufman et al., 2014; Kaufman et al., 2014). The model of orchiectomized animals has already been used in the literature to induce the animal to an osteopenic condition (Seifi et al., 2015).

The results obtained by laser confocal microscopy analysis showed that there is a significant difference between the male and female genders, when it comes to osteoporosis, especially regarding the rate of daily mineral bone apposition, which was higher in the tibia bones compared to the maxillary bones, since the ossification of the tibia is of the endochondral type while the maxilla is intramembranous.

In addition, ovariectomy and orchiectomy surgeries seem to decrease calcium precipitation, since the OVX and ORQ groups, both in the jaws and tibia, showed lower numerical value of the daily mineral apposition rate, characterizing an imbalance in bone dynamics. This imbalance is greater for females when compared to males.

The mineral apposition rate data (fluorescent markers) reveal strong evidence of acceleration of bone formation in ovariectomized rats. Unfortunately, the resorption rate cannot be measured directly by morphometry. Therefore, it can be inferred that the loss of bone mass indicates a large increase in bone resorption that exceeds the increase occurred in bone formation.

Therefore, and based on the scientific literature that corroborates the results of this study, we must pay attention to the fact that the risk of necrosis of the jaws mainly in women due to this difference in the rate of daily mineral bone apposition, followed by an exacerbated bone resorption. This characterizes an important clinical problem that should be considered by surgeons in relation to large bone reconstructions and implantology. We emphasize the importance of new studies to understand the bone dynamics that occur in osteoporosis and the importance of correct drug treatments, thus reducing the rate of appearance of osteonecrosis of the jaws.

\section{Conclusion}

Through the confocal laser microscopy, it was possible to conclude that the female gender, regarding the characteristics of the maxillary and tibial bone, presented a daily mineral apposition rate superior to the male gender, mainly in the maxillary bone, presenting a statistically significant difference between all the groups studied.

Then, after the evaluation in long bones and jaws without any injury, it was observed that there were differences between the behavior of bone formation of males in relation to females, so we think it is important in future works to evaluate the sexual dimorphism in conditions that have a reparational bone, that is, after the exodontia or installation of implants, it will be possible to observe how much bone will be formed after a bone injury, being possible the comparison with this study. 


\section{Acknowledgments}

This study was financially supported by the São Paulo Research Foundation - FAPESP with process numbers 2015/13712-4 and 2015/14688-0.

\section{References}

Akbaba, G., Isik, S., Ates Tutuncu, Y., Ozuguz, U., Berker, D., \& Guler, S. (2013). Comparison of alendronate and raloxifene for the management of primary hyperparathyroidism. Journal of endocrinological investigation, 36(11), 1076-1082. https://doi.org/10.3275/9095

Alghamdi, H. S., van den Beucken, J. J., \& Jansen, J. A. (2014). Osteoporotic rat models for evaluation of osseointegration of bone implants. Tissue engineering. Part C, Methods, 20(6), 493-505. https://doi.org/10.1089/ten.TEC.2013.0327

Al-Shahat, A. R., Shaikh, M. A., Elmansy, R. A., Shehzad, K., \& Kaimkhani, Z. A. (2011). Prostatic assessment in rats after bilateral orchidectomy and calcitonin treatment. Endocrine regulations, 45(1), 29-36.

Annibali, S., Cristalli, M. P., Dell'Aquila, D., Bignozzi, I., La Monaca, G., \& Pilloni, A. (2012). Short dental implants: a systematic review. Journal of dental research, 91(1), 25-32. https://doi.org/10.1177/0022034511425675

Aubin, J. E., \& Bonnelye, E. (2000). Osteoprotegerin and its ligand: A new paradigm for regulation of osteoclastogenesis and bone resorption. Medscape women's health, 5(2), 5

de Oliveira Puttini, I., Gomes-Ferreira, P., de Oliveira, D., Hassumi, J. S., Gonçalves, P. Z., \& Okamoto, R. (2019). Teriparatide improves alveolar bone modelling after tooth extraction in orchiectomized rats. Archives of oral biology, 102, 147-154. https://doi.org/10.1016/j.archoralbio.2019.04.007

Dempster, D. W., Compston, J. E., Drezner, M. K., Glorieux, F. H., Kanis, J. A., Malluche, H., Meunier, P. J., Ott, S. M., Recker, R. R., \& Parfitt, A. M. (2013). Standardized nomenclature, symbols, and units for bone histomorphometry: a 2012 update of the report of the ASBMR His tomorphometry Nomenclature Committee. Journal of bone and mineral research: the official journal of the American Society for Bone and Mineral Research, 28(1), 2-17. https://doi.org/10.1002/jbmr.1805

Drage, N. A., Palmer, R. M., Blake, G., Wilson, R., Crane, F., \& Fogelman, I. (2007). A comparison of bone mineral density in the spine, hip and jaws of edentulous subjects. Clinical oral implants research, 18(4), 496-500. https://doi.org/10.1111/j.1600-0501.2007.01379.x

Drake, M. T., \& Khosla, S. (2012). Male osteoporosis. Endocrinology and metabolism clinics of North America,41(3), 629-641. https://doi.org/10.1016/j.ecl.2012.05.001

Farahmand, P., Spiegel, R., \& Ringe, J. D. (2016). Männliche Osteoporose [Male osteoporosis]. Zeitschrift fur Rheumatologie, 75(5), 459-465. https://doi.org/10.1007/s00393-016-0078-2

Gennari, L., Nuti, R., \& Bilezikian, J. P. (2004). Aromatase activity and bone homeostasis in men. The Journal of clinical endocrinology and metabolism, 89(12), 5898-5907. https://doi.org/10.1210/jc.2004-1717

Giusti, A., \& Bianchi, G. (2014). Treatment of primary osteoporosis in men. Clinical interventions in aging, 10, 105-115. https://doi.org/10.2147/CIA.S44057

Hassler, N., Roschger, A., Gamsjaeger, S., Kramer, I., Lueger, S., van Lierop, A., Roschger, P., Klaushofer, K., Paschalis, E. P., Kneissel, M., \& Papapoulos, S. (2014). Sclerostin deficiency is linked to altered bone composition. Journal of bone and mineral research: the official journal of the American Society for Bone and Mineral Research, 29(10), 2144-2151. https://doi.org/10.1002/jbmr.2259

Häuselmann, H. J., \& Rizzoli, R. (2003). A comprehensive review of treatments for postmenopausal osteoporosis. Osteoporosis international : a journal established as result of cooperation between the European Foundation for Osteoporosis and the National Osteoporosis Foundation of the USA, 14(1), 2-12. https://doi.org/10.1007/s00198-002-1301-3

Kaufman, J. M., \& Goemaere, S. (2008). Osteoporosis in men. Best practice \& research. Clinical endocrinology \& metabolism, 22(5), 787-812. https://doi.org/10.1016/j.beem.2008.09.005

Kaufman, J. M., Lapauw, B., \& Goemaere, S. (2014). Current and future treatments of osteoporosis in men. Best practice \& research. Clinical endocrinology \& metabolism, 28(6), 871-884. https://doi.org/10.1016/j.beem.2014.09.002

Kilkenny, C., Browne, W. J., Cuthi, I., Emerson, M., \& Altman, D. G. (2012). Improving bioscience research reporting: the ARRIVE guidelines for reporting animal research. Veterinary clinical pathology, 41(1), 27-31. https://doi.org/10.1111/j.1939-165X.2012.00418.x

Luvizuto, E. R., Queiroz, T. P., Dias, S. M., Okamoto, T., Dornelles, R. C., Garcia, I. R., Jr, \& Okamoto, R. (2010). Histomorphometric analysis and immunolocalization of RANKL and OPG during the alveolar healing process in female ovariectomized rats treated with oestrogen or raloxifene. Archives of oral biology, 55(1), 52-59. https://doi.org/10.1016/j.archoralbio.2009.11.001

Manolagas, S. C., \& Jilka, R. L. (1995). Bone marrow, cytokines, and bone remodeling. Emerging insights into the pathophysiology of osteoporosis. The New England journal of medicine, 332(5), 305-311. https://doi.org/10.1056/NEJM199502023320506

Marie P. J. (2006). Strontium ranelate: a dual mode of action rebalancing bone turnover in favour of bone formation. Current opinion in rheumatology, 18 Suppl 1, S11-S15. https://doi.org/10.1097/01.bor.0000229522.89546.7b 
Marie, P. J., Hott, M., Modrowski, D., De Pollak, C., Guillemain, J., Deloffre, P., \& Tsouderos, Y. (1993). An uncoupling agent containing strontium prevents bone loss by depressing bone resorption and maintaining bone formation in estrogen-deficient rats. Journal of bone and mineral research : the official journal of the American Society for Bone and Mineral Research, 8(5), 607-615. https://doi.org/10.1002/jbmr.5650080512

Marx, R. E., Cillo, J. E., Jr, \& Ulloa, J. J. (2007). Oral bisphosphonate-induced osteonecrosis: risk factors, prediction of risk using serum CTX testing, prevention, and treatment. Journal of oral and maxillofacial surgery: official journal of the American Association of Oral and Maxillofacial Surgeons, 65(12), 2397-2410. https://doi.org/10.1016/j.joms.2007.08.003

McClung, M. R., Lewiecki, E. M., Cohen, S. B., Bolognese, M. A., Woodson, G. C., Moffett, A. H., Peacock, M., Miller, P. D., Lederman, S. N., Chesnut, C. H., Lain, D., Kivitz, A. J., Holloway, D. L., Zhang, C., Peterson, M. C., Bekker, P. J., \& AMG 162 Bone Loss Study Group (2006). Denosumab in postmenopausal women with low bone mineral density. The New England journal of medicine, 354(8), 821-831. https://doi.org/10.1056/NEJMoa044459

Mittan, D., Lee, S., Miller, E., Perez, R. C., Basler, J. W., \& Bruder, J. M. (2002). Bone loss following hypogonadism in men with prostate cancer treated with GnRH analogs. The Journal of clinical endocrinology and metabolism, 87(8), 3656-3661. https://doi.org/10.1210/jcem.87.8.8782

NIH Consensus Development Panel on Osteoporosis Prevention, Diagnosis, and Therapy (2001). Osteoporosis prevention, diagnosis, and therapy. JAMA, 285(6), 785-795. https://doi.org/10.1001/jama.285.6.785

Oliveira, L. G., \& Guimarães, M. L. (2015). Male Osteoporosis. Revista brasileira de ortopedia,45(5), 392-396. https://doi.org/10.1016/S22554971(15)30425-0

Pacifici, R., Rifas, L., McCracken, R., Vered, I., McMurtry, C., Avioli, L. V., \& Peck, W. A. (1989). Ovarian steroid treatment blocks a postmenopausal increase in blood monocyte interleukin 1 release. Proceedings of the National Academy of Sciences of the United States of America, 86(7), 2398-2402. https://doi.org/10.1073/pnas.86.7.2398

Pedrosa, W. F., Jr, Okamoto, R., Faria, P. E., Arnez, M. F., Xavier, S. P., \& Salata, L. A. (2009). Immunohistochemical, tomographic and histological study on onlay bone graft remodeling. Part II: calvarial bone. Clinical oral implants research, 20(11), 1254-1264. https://doi.org/10.1111/j.1600-0501.2009.01747.x

Pereira, A. S; Shitsuka, D. M; Pereira, F. J; Shitsuka, R. (2018). Scientific research methodology. Ed. UAB / NTE / UFSM. https://repositorio.ufsm.br/bitstream/handle/1/15824/Lic_Computacao_Metodologia-Pesquisa-Cientifica.pdf?sequence=1 .

Ramalho-Ferreira, G., Faverani, L. P., Grossi-Oliveira, G. A., Okamoto, T., \& Okamoto, R. (2015). Alveolar bone dynamics in osteoporotic rats treated with raloxifene or alendronate: confocal microscopy analysis. Journal of biomedical optics, 20(3), 038003. https://doi.org/10.1117/1.JBO.20.3.038003

Ramalho-Ferreira, G., Faverani, L. P., Momesso, G., Luvizuto, E. R., de Oliveira Puttini, I., \& Okamoto, R. (2017). Effect of antiresorptive drugs in the alveolar bone healing. A histometric and immunohistochemical study in ovariectomized rats. Clinical oral investigations, 21(5), 1485-1494. https://doi.org/10.1007/s00784-016-1909-x

Riggs, B. L., Khosla, S., \& Melton, L. J., 3rd (2002). Sex steroids and the construction and conservation of the adult skeleton. Endocrine reviews, 23(3), 279302. https://doi.org/10.1210/edrv.23.3.0465

Ruggiero, S. L., Dodson, T. B., Fantasia, J., Goodday, R., Aghaloo, T., Mehrotra, B., O'Ryan, F., \& American Association of Oral and Maxillofacial Surgeons (2014). American Association of Oral and Maxillofacial Surgeons position paper on medication-related osteonecrosis of the jaw--2014 update. Journal of oral and maxillofacial surgery: official journal of the American Association of Oral and Maxillofacial Surgeons, 72(10), 1938-1956. https://doi.org/10.1016/j.joms.2014.04.031

Sayed, A. A., Soliman, A. M., Fahmy, S. R., Marzouk, M. (2013) Antiosteoporotic effect of Coelatura aegyptiaca shell powder on ovariectomized rats. African Journal of Pharmacy and Pharmacology 7(34), 2406-2416. https://doi.org/10.5897/AJPP2013.3817

Seeman E. (2003). Reduced bone formation and increased bone resorption: rational targets for the treatment of osteoporosis. Osteoporosis international : a journal established as result of cooperation between the European Foundation for Osteoporosis and the National Osteoporosis Foundation of the USA, 14 Suppl 3, S2-S8. https://doi.org/10.1007/s00198-002-1340-9

Seifi, M., Ezzati, B., Saedi, S., \& Hedayati, M. (2015). The Effect of Ovariectomy and Orchiectomy on Orthodontic Tooth Movement and Root Resorption in Wistar Rats. Journal of dentistry (Shiraz, Iran), 16(4), 302-309.

Stevenson, M., Jones, M. L., De Nigris, E., Brewer, N., Davis, S., \& Oakley, J. (2005). A systematic review and economic evaluation of alendronate, etidronate, risedronate, raloxifene and teriparatide for the prevention and treatment of postmenopausal osteoporosis. Health technology assessment (Winchester, England), 9(22), 1-160. https://doi.org/10.3310/hta9220 G.

Vanderschueren, D., Vandenput, L., Boonen, S., Lindberg, M. K., Bouillon, R., \& Ohlsson, C. (2004). Androgens and bone. Endocrine reviews, 25(3), 389425. https://doi.org/10.1210/er.2003-0003

Van Pottelbergh, I., Goemaere, S., \& Kaufman, J. M. (2003). Bioavailable estradiol and an aromatase gene polymorphism are determinants of bone mineral density changes in men over 70 years of age. The Journal of clinical endocrinology and metabolism, 88(7), 3075-3081. https://doi.org/10.1210/jc.2002021691

Wang, N., Docherty, F. E., Brown, H. K., Reeves, K. J., Fowles, A. C., Ottewell, P. D., Dear, T. N., Holen, I., Croucher, P. I., \& Eaton, C. L. (2014). Prostate cancer cells preferentially home to osteoblast-rich areas in the early stages of bone metastasis: evidence from in vivo models. Journal of bone and mineral research: the official journal of the American Society for Bone and Mineral Research, 29(12), 2688-2696. https://doi.org/10.1002/jbmr.2300 